\section{Bio Core}

Exploring Scientific Community
International Journal of Nutritional Science and Food Technology

\title{
The Best Diet Depends on Your Age
}

\section{Italia Guzman}

Tangible Nous SA of CV, San Luis Potosí Area, Mexico

Corresponding Author: Italia Guzman, Tangible Nous SA of CV, San Luis Potosí Area, Mexico.

Email: italia.guzman@gmail.com

Citation: Italia Guzman (2016), The Best Diet Depends on Your Age. Int J Nutr Sci \& Food Tech. 2:1, 10-11.

DOI: $10.25141 / 2471-7371-2016-1.0040$

Copyright: (O2016 Italia Guzman. This is an open-access article distributed under the terms of the Creative Commons Attribution License, which permits unrestricted use, distribution, and reproduction in any medium, provided the original author and source are credited

Received January 29, 2016, Accepted February 6, 2016, Published February 28, 2016

Key words: Pomegranate, Carbonated Beverage, Pomegranate Juice, Ginger Juice

\section{Introduction}

Nutrition is understood as the intake of food that should be supported by the energy that the body requires. Good nutrition is confirmed by having a balanced diet together with regular physical activity. However one of the main questions is: What amount of nutrients should be taken for good health? This article covers information about one of these nutrients, which is extremely important due to its high energy content: "Proteins".

\section{Understanding Proteins}

Proteins are built by thousands of chemical units called "amino acids", those units are naturally produced by the organism. However, there are essential amino acids that need to be extracted from different sources of protein:

Animal proteins: They contain all the essential amino acids and these proteins are called "complete or whole proteins".

Vegetable proteins: (fruits, grains, seeds) these proteins contain one or more essential amino acids therefore are called "partial proteins".

Even though it seems animal food are better for the fact of being complete, there are other elements especially found in red meat and dairy product that in high levels can generate severe diseases. An example is the hearth disease caused by cholesterol, saturated fats and excess of calories.

In case of low or no protein food consumption, the organism uses the fat and glycogen reserves but once they are exhausted, the amino acids in the proteins act as a source of energy, damaging the tissue's natural maintenance, growth and restoration resulting on malnutrition syndromes with and obvious health deterioration. So, how much protein should you eat?

A scientific study published in the online magazine "Cell
Metabolism" in 2014, considered a sample of 6,381 adults under 65 years of age and suggests that middle-aged people should not consume high levels of protein particularly animal protein because it quadruples the risk of developing cancer. However, for a person aged 65 or more, a diet rich in meat and animal products can help extending his/her life.

The result indicates that those under 65 years old with high animal protein consumption were more likely to die of cancer and diabetes. However, those over 65 years old with protein intake were $60 \%$ less likely to die of cancer.

According to the study researches, the reason may be a protein that controls the growth of the hormone IGF -I that is linked to cancer susceptibility because when is developed, it promotes cancer cells growth. But after 65 years, the hormone levels drops causing weakness and loss of muscle mass.

However the researchers involved in the study found that the vegetable protein in grains does not have the same effect on mortality than the animal protein, since cancer rates and mortality were not affected by the consumption of carbohydrates and vegetable fats, therefore, it is concluded that the main effect is due to the consumption of animal protein. Still, it is not recommended eliminate animal proteins from the diet because could lead a quick malnutrition.

According to the scientific study published on the on line magazine Cell Metabolism in 2014 suggested that it is recommended to eat 46 grams of protein for women over 19 years, and 56 grams for men over 19 years.

So the last answer of science about how much protein should be consumed depends on the individual's age; it is important to consider a balanced diet authorized by an expert and never forget to practice exercise regularly. 
Nowadays there are many options that complement the consumption of animal protein, like vegetable alternatives that generate a positive impact on health by reducing the collateral conditions that are generated by the excessive animal protein intake.

Vegetable protein sources also provide other nutritional benefits such as the increased consumption of fiber, minerals and Phytonutrients that could stop diseases because the intake of saturated fat and cholesterol is reduced.

The consequences of using alternative plants are directly reflected in the preservation of the environment, and now the industry realizes that is important to use sustainable works alternatives that generate greater value in the consumer and at the same time consumers are becoming more aware that change is generated directly in all actions that are performed daily and the consumption of green products its the new choice, reduce the footprint of our coexistence in nature.

\section{References}

1. European Food Information Council (2005) Las proteínas son esenciales para la vida. 21/01/2016 de European Food Information Council Sitio web: http://www.eufic.org/article/es/salud-estilo-devida/comida-sana/artid/proteinas/

2. DJ Frenk (2016) Protein de Harvard T.C Chan Sitio web: http:// www.hsph.harvard.edu/nutritionsource/what-should-you-eat/ protein/

3. BBC MUNDO (2016) Las proteínas pueden ser buenas o malas según la edad. de BBC MUNDO Sitio web: http://www.bbc.com/ mundo/noticias/2014/03/140305_salud_dieta_proteina_edad_gtg

4. Morgan E. Levine, Jorge A. Suarez, Sebastian Brandhorst, Priya Balasubramanian, Chia-Wei Cheng, Federica Madia, Luigi Fontana, Mario G. Mirisola, Jaime Guevara-Aguirre, Junxiang Wan, Giuseppe Passarino, Brian K Kennedy, Min Wei, Pinchas Cohen, Eileen M Crimmins, Valter D Longo (2014). Low Protein Intake Is Associated with a Major Reduction in IGF-1, Cancer, and Overall Mortality in the 65 and Younger but Not Older Population. Cell Metabolism, 19: 407-417. De Cell Metabolism Base de datos. 